\title{
Pembelajaran Perguruan Tinggi Dalam Jaringan (Daring) Masa Pandemi Covid-19
}

\author{
Murti Wijayanti ${ }^{1, *}$, Tyna Yunita ${ }^{1}$, Agus Dharmanto ${ }^{1}$ \\ ${ }^{1}$ Fakultas Ekonomi dan Bisnis; Universitas Bhayangkara Jakarta Raya; Jl. Raya \\ Perjuangan, Marga Mulya, Bekasi Utara, Jawa Barat 17121, Telp: 021-88955882, 88955883; \\ email: murti.wijayanti@dsn.ubharajaya.ac.id; tyna.yunita@gmail.com; \\ agus.dharmanto@dsn.ubharajaya.ac.id \\ * Korespondensi: e-mail: murti.wijayanti@dsn.ubharajaya.ac.id
}

\begin{abstract}
The education world now is entering an adjustment phase in teaching and learning process during the Covid-19 pandemic. Activities that are usually carried out offline (outside the network) face-to-face in the classroom, turn into online distance learning (in the network). In order to reduce the spread of the virus, the government issued a policy stating that all activities are carried out from home and utilize the technology as a supporting tool, including learning practices carried out by the universities. The limited online learning conditions between lecturers and students, overcome by the campus by preparing themselves to formulate policies and strategic steps, so that, the activity process on sharing topics lecture continue to run using elearning application facilities. Likewise, Tri Dharma activities of higher education regarding research and community service. The use of technology with various platform applications during this pandemic is one of the researches breakthroughs used. Like it or not, online learning forces both lecturer and students to adapt. Implementation of community service activities that are generally carried out directly in the field, continues to run using the internet network through the provision of webinars (seminars on the web) or virtual work lecture $(K K N)$ activities virtually.
\end{abstract}

Keywords: Outside the Network, Distance Learning, In the Network, University

\begin{abstract}
Abstrak
Dunia pendidikan saat ini memasuki fase penyesuaian dalam proses belajar mengajar di masa pandemi Covid-19. Kegiatan yang biasanya dilakukan secara luring (luar jaringan) tatap muka di ruang kelas, beralih menjadi pembelajaran jarak jauh dengan daring (dalam jaringan). Dalam rangka menekan laju penyebaran virus, pemerintah mengeluarkan kebijakan yang menyatakan bahwa semua aktivitas kegiatan dilakukan dari rumah dan memanfaatkan teknologi sebagai sarana penunjangnya, termasuk praktik pembelajaran yang dijalankan oleh perguruan tinggi. Kondisi pembelajaran yang terbatas secara daring antara dosen dan mahasiswa, diatasi pihak kampus dengan mempersiapkan diri menyusun kebijakan dan langkah strategis agar proses aktivitas kegiatan berbagi materi topik kuliah tetap berjalan menggunakan fasilitas aplikasi $e$ learning. Begitu pula dengan kegiatan Tri Dharma perguruan tinggi dalam hal riset dan pengabdian masyarakat. Penggunaan teknologi dengan bermacam platform aplikasi di masa pandemi ini merupakan salah satu terobosan riset yang digunakan. Mau tidak mau, suka tidak suka, pembelajaran secara daring "memaksa" para tenaga didik dan juga mahasiswa untuk beradaptasi. Pelaksanaan kegiatan pengabdian masyarakat yang umumnya dilakukan secara langsung di lapangan, tetap berjalan menggunakan jaringan internet melalui pengadaan webinar (seminar dalam web) atau kegiatan kuliah kerja nyata (KKN) secara virtual.
\end{abstract}

Kata kunci: Luar Jaringan, Pembelajaran Jarak Jauh, Dalam Jaringan, Perguruan Tinggi 


\section{Pendahuluan}

Merebaknya wabah virus Covid-19 (Corona Virus Disease-19) di kota Wuhan, Tiongkok pada akhir tahun 2019 dan dirilisnya ketetapan resmi dari lembaga kesehatan dunia WHO yang menyatakan status bahwa wabah tersebut menjadi pandemi di seluruh belahan dunia, termasuk Indonesia yang memproklamirkan ditemukan kasus pertama di awal Maret 2020. Hal tersebut menjadikan negara aktif meningkatkan kewaspadaan dengan membentuk tim gugus percepatan penanganan guna mendukung pencegahan meluasnya penyebaran infeksi virus Covid-19. Meningkatnya jumlah angka kasus positif yang terkena virus serta munculnya istilah baru terkait pandemi seperti ODP (Orang Dalam Pemantauan), PDP (Pasien Dalam Pengawasan) dan OTG (Orang Tanpa Gejala) berdampak pada seluruh roda kehidupan tatanan masyarakat negara tidak terkecuali sektor pendidikan.

Melalui kebijakan program pemerintah yang diwakili Kementerian Kesehatan dan Kementerian Pendidikan dan Kebudayaan (Kemendikbud) serta penyampaian data dan informasi perkembangan global infeksi Covid-19 dari instansi gugus tugas, beberapa kampus di Indonesia sesuai dengan arahan dan ketentuan yang ditetapkan telah melakukan penghentian proses kegiatan belajar-mengajar secara langsung atau tatap muka dan mengimbau agar perguruan tinggi memantau dan membantu kelancaran para mahasiswanya melakukan pembelajaran dari rumah (study from home) dan menggantinya dengan kuliah daring (dalam jaringan) atau online (Pakpahan \& Fitriani, 2020).

Dalam mengatasi wabah COVID-19, pemerintah tidak melakukan karantina wilayah (lock down) tetapi menggunakan kebijakan Pembatasan Sosial Berskala Besar (PSBB). Dimulai dari ibukota Jakarta, kebijakan ini diikuti oleh wilayah lainnya. Kota Bekasi sebagai wilayah penyangga Jakarta segera menerapkan kebijakan PSBB mengingat wilayah ini berdekatan dengan dikhawatirkan terpengaruh dengan kota Jakarta yang merupakan zona merah dengan hampir separuh kasus COVID-19 ada di wilayah Jakarta. Banyak pihak yang mendukung dan juga kurang setuju dengan PSBB, namun agar perekonomian tetap berjalan dan wabah dapat diatasi, pemerintah tidak mengambil kebijakan karantina wilayah. Untuk mengetahui efektifitas PSBB di kota Bekasi, penelitian ini mencoba menggunakan model SusceptibleInfectedRecoverd (SIR) untuk mengukur laju penyebaran COVID-19. Hasilnya menunjukan adanya laju penurunan kasus terinfeksi dengan beta dan gamma beruturut-turut sebesar 0,071 dan 0,05 dan diprediksi akan berakhir di bulan Juni 2020. (Handayanto \& Herlawati, 2020).

Hal tersebut didukung oleh beberapa riset di seluruh dunia dalam memprediksi puncak sebaran COVID-19 yang beberapa negara sudah masuk dalam masa lonjakan kedua. Untuk wilayah Indonesia beberapa peneliti menggunakan pendekatan soft computing, seperti Support Vector Machine (SVM) regression, dengan beberapa kernel pilihan, antara lain radial basis function, linear and polynomial dengan akurasi yang beragam. Alat bantu dari Google (Google Interactive Notebook) sangat membantu dengan fasilitas kompiler dan servernya (Herlawati, 2020). 
Tulisan ini berisi pembahasan terkait pembelajaran di perguruan tinggi dalam jaringan (daring) pada masa pandemi Covid-19 dengan menggunakan studi beberapa sumber literatur.

\section{Metode Penelitian}

Berangkat dari situasi yang dialami, tulisan ini dirangkai dalam bentuk penelitian kualitatif yang menganalisa data informasi berdasarkan review studi literatur dengan pendekatan deskriptif yang bertujuan mengeksplorasi dan mengungkapkan fenomena sosial yang akan diteliti dan dipahami secara menyeluruh, luas dan mendalam untuk mengembangkan teori yang dibangun sehingga diperoleh gambaran umum situasi (Sugiyono, 2018). Untuk memahami fenomena yang terjadi, penelitian kualitatif ini dianalisa dengan melakukan eksplorasi secara grand tour observation menggunakan grand tour question terhadap obyek yang akan diteliti dengan berfokus pada informasi dari situasi sosial di lapangan (pembelajaran perguruan tinggi) terkait pandemi Covid-19.

\section{Hasil dan Pembahasan}

\subsection{Kebijakan dan Langkah Strategis Kampus}

Mengutip isi Surat Edaran dari Mendikbud (Kemdikbud, 2020) terdapat ketentuan yang dirangkum dan disampaikan oleh Direktorat Jenderal Pendidikan Tinggi (Dirjen Dikti), diantaranya : 1. Teknis pengaturan periode pembelajaran dan penyelenggaraan kegiatan pembelajaran untuk seluruh jenjang program pendidikan diserahkan kepada kebijakan Pimpinan Perguruan Tinggi yang disesuaikan dengan kebutuhan dan mempertimbangkan situasi dan kondisi serta berkoordinasi dengan Lembaga Layanan Pendidikan Tinggi (LLDIKTI) setempat; 2. Pelaksanaan kegiatan praktek di lapangan yang menggunakan tempat penelitian khusus (laboratorium) serta kegiatan penelitian tugas akhir baik metode dan jadwalnya disesuaikan dengan situasi dan kondisi di lingkungan daerah.

Himbauan SE Mendikbud yang disosialisasikan oleh Direktur Jenderal Pendidikan Tinggi (Dikti) diterapkan di lingkungan internal civitas akademika Universitas Bhayangkara dengan menerbitkan Surat Edaran serta memberlakukan mekanisme perkuliahan daring atau pembelajaran jarak jauh (PJJ) yang pelaksanaannya sampai dengan akhir Semester Genap Tahun Ajaran 2019/2020. Ketentuan tersebut diadopsi oleh internal kampus ke dalam beberapa langkah strategis yang telah dilaksanakan (Ubharajaya.ac.id), antara lain:

1. Dukungan teknologi informasi penguatan platform pembelajaran daring, dan melakukan negosiasi dengan pihak penyedia jasa internet untuk menggratis-kan laman pendidikan dan paket internet ramah kantong bagi para mahasiswa yang bekerja sama dengan

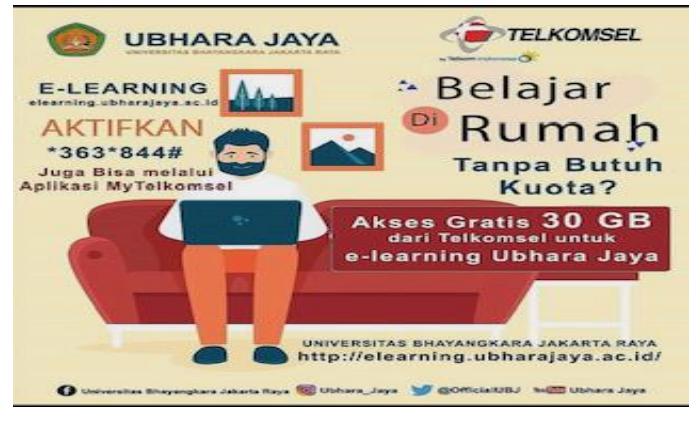

Gambar 1. Kerjasama Akses Internet 
salah satu provider. (Gambar 1)

2. Selama masa pembelajaran daring, pihak universitas dapat memberikan keringanan penundaan pembiayaan perkuliahan mahasiswa dengan mengajukan surat ke instansi terkait, termasuk pemberian subsidi kuota internet dengan syarat dan kondisi yang telah ditentukan. (Gambar 2)

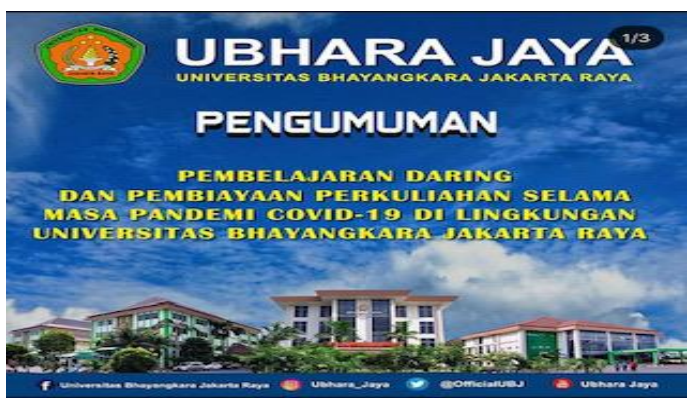

Gambar 2. Keringanan Pembiayaan Perkuliahan

3. Untuk menjaga kebersihan di lingkungan civitas akademik, dilakukan penyemprotan disinfektan secara periodik semua fasilitas universitas, serta menyediakan fasilitas kesehatan tambahan seperti hand sanitizer dan sabun pencuci tangan disamping aktif mensiagakan fasilitas unit kesehatan kampus.

\subsection{Kegiatan Pembelajaran dan Implementasi di Masa Pandemi.}

Implementasi pembelajaran di masa pandemi mengusung konsep "merdeka belajar" yang dicanangkan Mendikbud sebagai kebijakan pembelajaran nasional baru yang esensinya adalah menggali potensi para tenaga pendidik dari para siswa ataupun mahasiswa terdidik untuk berinovasi dan meningkatkan kualitas pembelajaran secara mandiri. Melalui konsep ini, kebijakan dalam mereformasi sistem pendidikan sebagai konsep inovasi yang memberikan kemerdekaan pada tiap unit pendidikan tanpa keluar dari esensi pendidikan itu sendiri dengan cara peningkatan kualitas tenaga pendidik yang tidak akan dapat digantikan dengan teknologi sebagai tools alat bantu pendukung, serta kurikulum pembelajaran yang mudah dipahami dan fleksibel.

Keberagaman minat dan kemampuan yang dimiliki oleh siswa atau mahasiswa menjadi salah satu alasan kuat bahwa pengukuran output kinerja tidak hanya dinilai dari angka pencapaian akademik, tetapi juga melalui bermacam aktivitas kegiatan diluar lingkungan pendidikan. Oleh karenanya kegiatan pemahaman materi pembelajaran secara kontekstual berdasarkan luring (luar jaringan) juga memasukkan unsur pembelajaran aktivitas diluar kelas dan terakomodasi dalam kurikulum. Salah satu pencapaiannya dilaksanakan dengan melakukan pembelajaran jarak jauh secara daring (dalam jaringan) sebagai bentuk dukungan teknologi (Kemdikbud, 2020).

Di masa situasi pandemi ini semua pihak merasakan keluar dari area kenyamanan masing-masing, sehingga karakter adaptasi, inovasi dan kreasi dari komunitas pendidikan tertantang untuk dilatih. Tantangan dan kendala ini ditanggapi dengan cara pendekatan humanis selama melakukan aktivitas pembelajaran jarak jauh melalui model pembelajaran yang dilakukan mahasiswa yang tidak hanya terbatas pada ruang kelas, perpustakaan dan laboratorium semata, tetapi dengan melakukan proyek mandiri, penelitian bersama dosen atau peneliti ataupun terlibat langsung pada kegiatan program kemanusiaan. 
Perkembangan ilmu pengetahuan dan teknologi yang pesat berdampak pada perubahan model pembelajaran di perguruan tinggi. Kebijakan pimpinan universitas untuk menggunakan sistem pembelajaran daring berbasis website (e-learning) diimplementasikan dan diakses pada alamat website www.e-learning.ubharajaya.ac.id dalam bentuk aplikasi moodle (Modular Object Oriented Dynamic Learning Environment) yang tampilan halaman muka ditunjukkan seperti pada gambar 3.3. Aplikasi yang terdiri dari 3 pemakai, yaitu administrator, dosen dan mahasiswa dimaksimalkan untuk menunjang pembelajaran daring di internal kampus. Administrator sebagai pengendali utama aplikasi, dosen sebagai pengelola materi perkuliahan, tugas, quiz dan nilai, sedangkan mahasiswa dapat melihat materi perkuliahan untuk dipelajari, mengerjakan tugas dan quiz, dan melihat nilai yang didapatkan. Kegiatan sosialiasi baik untuk dosen maupun mahasiswa dilakukan administrator setiap minggu untuk mengevaluasi serta mengupdate kendala dan masukan yang terjadi selama masa pembelajaran dalam rangka penerapan e-learning, termasuk membuat pusat bantuan (helper desk) informasi melalui telepon maupun aplikasi whatsapp.

Aplikasi ini dapat membantu dosen untuk memantau partisipasi mahasiswa dalam kegiatan pembelajaran, dimana mahasiswa dapat saling berinteraksi antara satu sama lain bahkan dengan para dosen mata kuliah tersebut. Moodle tidak memaksa dosen merubah gaya mengajarnya, tetapi pengembangan aplikasi e-learning ini seharusnya dapat mendukung pembelajaran yang dilakukan oleh dosen (Rohman \& Munif, 2020).

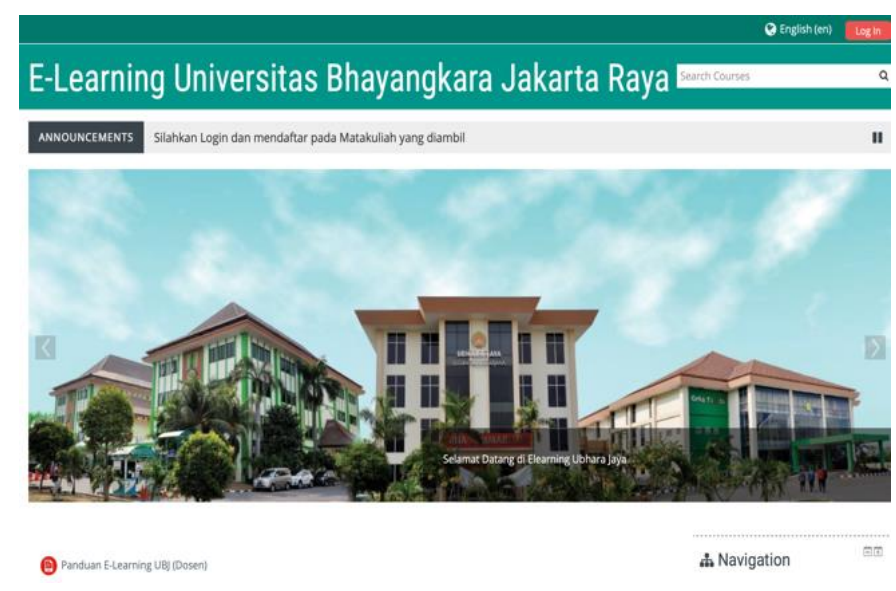

Gambar 3. Tampilan muka E-learning

\subsection{Terobosan Riset dan Inovasi}

Implementasi dan pelaksanaan Tri Dharma pada masa pandemi ini diwujudkan dengan adanya kolaborasi antara beberapa perguruan tinggi, lembaga penelitian dan pengembangan, institusi pemerintah dan non pemerintah yang saling bergotong royong dan turut andil mengambil bagian melakukan riset penelitian. Bahkan diantaranya telah menghasilkan bermacam inovasi di bidang kesehatan untuk penanganan Covid-19 (Kemendikbud, 2020). Apresiasi yang sangat tinggi dan baik diberikan kepada para institusi yang menanggapi respon kelangkaan pemenuhan kebutuhan medis dengan cepat melalui riset jangka pendek. 
Dalam rangka pencegahan penyebaran virus Covid-19, melalui surat edaran, Kemendikbud Dikti telah menyiapkan beberapa aplikasi yang dapat dimanfaatkan dan digunakan secara massal oleh perguruan tinggi untuk saling berbagi mata kuliah secara daring. Mulai dari PJJ, Inherent, iD-Ren, SPADA, aplikasi tersebut diselenggarakan bekerjasama dengan content provider seperti Indonesia Cyber Education, Google Suite, Amazon web services, dan Nvdia-Artificial Intelligence Courses serta menghimbau pimpinan universitas untuk membuka akses pembelajaran jarak jauh tersebut di masing-masing perguruan tinggi agar dapat diakses oleh kampus perguruan tinggi lain (dikti.kemendikbud.go.id).

Salah satu aplikasi tingkat nasional yang dapat dimanfaatkan dan disediakan tidak berbayar sebagai media layanan pembelajaran dosen dan mahasiswa adalah SPADA (Sistem Pembelajaran Daring Indonesia) yang dikembangkan berdasarkan learning management system. Inovasi pada sistem ini menjawab beberapa tantangan Pendidikan tinggi yang belum memiliki sumber daya Pendidikan yang memadai dan berkualitas, rendahnya layanan Pendidikan tinggi yang setara dan bermutu, serta keterbatasan jangkauan sebaran lokasi perguruan tinggi (SPADA Indonesia, 2019).

\subsection{Pengabdian Kepada Masyarakat}

Kegiatan Tri Dharma Perguruan Tinggi pengabdian kepada masyarakat di masa pandemi Covid-19 tetap berjalan secara daring meskipun dengan keterbatasan ruang gerak. Bentuk kegiatan diwujudkan dari keikutsertaan pada acara conference video webinar yang diadakan oleh berbagai institusi Pendidikan maupun non Pendidikan melalui kanal saluran maya. Pada kesempatan tersebut, aktivitas berbagi topik materi ilmu, menambah kreativitas dan keterampilan serta saling bertukar pengalaman dan wawasan kepada masyarakat yang umumnya dilakukan secara bertatap muka langsung di lapangan, beralih proses menggunakan metode aplikasi berbasis teknologi menggunakan komputer maupun perangkat komunikasi. Tidak jarang juga pelaksanaan kegiatan pengabdian kepada masyarakat menggunakan metode tersebut dihadapkan pada kendala keterbatasan dalam hal jaringan yang tidak kondusif, meskipun tidak mengubah esensi dari isi kegiatannya.

Dalam rangka tetap menjalankan program kerja perguruan tinggi yang telah diagendakan sebelumnya, yaitu kegiatan pengabdian masyarakat KKN (kuliah kerja nyata) secara virtual. Mahasiswa tidak terjun langsung tinggal di pemukiman masyarakat, namun mereka diminta untuk melakukan pendampingan jarak jauh melalui sambungan telepon ataupun telekonferensi video (Kompas.id).

Upaya lain dari pihak universitas dalam mengatasi masalah pandemi melawan dan menangani Covid-19, adalah pelaksanaan kerjasama eksternal dengan Dikjen Dikti untuk berpartisipasi melakukan sosialisasi pembukaan rekrutmen mahasiswa relawan kemanusiaan melalui media sosial kampus. Dalam flyer pada gambar 3.4 tersebut, diinformasikan beberapa pilihan fokus kegiatan relawan yang terdiri dari edukasi, tracking, screening, dan penanganan pasien termasuk penjelasan mengenai protokol dan kriteria relawan mahasiswa. 


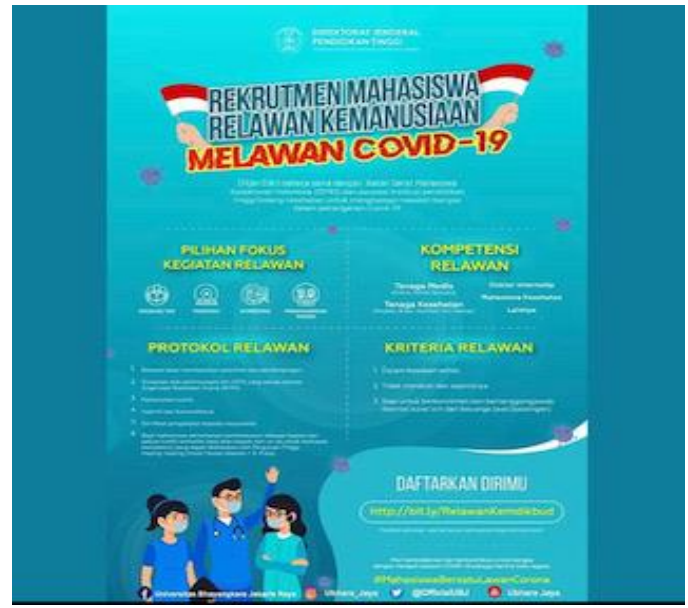

Gambar 4. Kegiatan Relawan Kemanusiaan

Selain itu, dari sisi internal universitas pada flyer gambar 3.5, dilakukan kegiatan penggalangan donasi bantuan distribusi paket sembako bagi masyarakat yang terdampak Covid-19 di lingkungan Universitas Bhayangkara yang salah satunya diakomodir oleh Keluarga Islam Mahasiswa Universitas Bhayangkara Jakarta Raya (KIMURA) beranggotakan mahasiswa Fakultas Ekonomi Akuntansi.

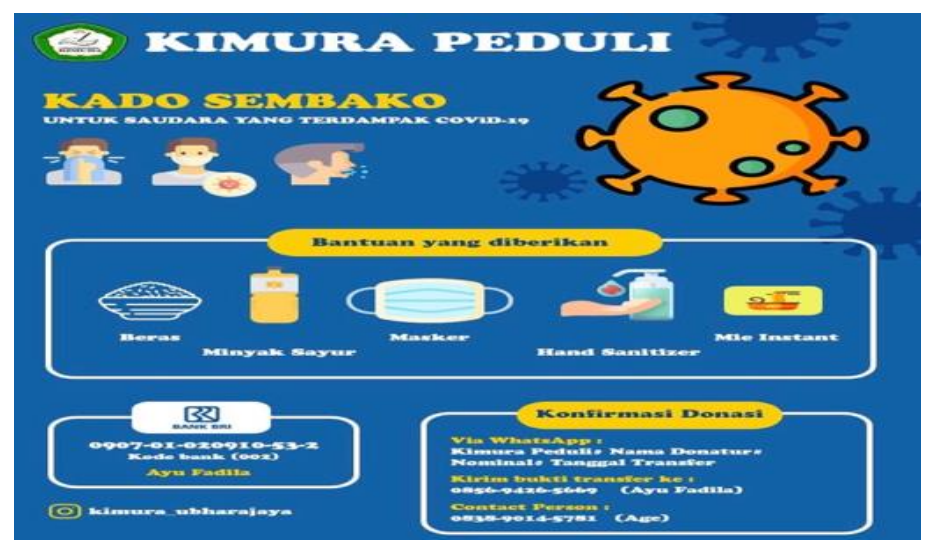

Gambar 5. Penggalangan Donasi

\section{Kesimpulan}

Pandemi Covid-19 belum menunjukkan tanda akan mereda. Memasuki fase kehidupan baru yang normal (new normal), pemerintah terus melakukan penyusunan strategi dan standar operasional prosedur. Pola pembelajaran yang diperoleh selama daring study from home menjadikan pengalaman serta masukan bagi semua pihak untuk terus berperan, bersinergi dan bekerja sama dalam penanganan pandemi. Bagian Humas Kemendikbud Dikti menyampaikan bahwa tidak semua perguruan tinggi memiliki platform pembelajaran secara daring, pernyataan tersebut dibuktikan dari hasil survey terkait indeks pembelajaran secara daring dalam kurun waktu 1 bulan, sebanyak 94,73\% dari 237.193 responden mahasiswa telah melakukan pembelajaran daring. Sisanya, dalam pelaksanaan daring tersebut masih terdapat kendala dalam hal koneksi internet, aplikasi yang digunakan, kualitas penyajian dan fasilitas topik materi. Harapannya, seluruh perguruan tinggi saling berbagi modul pembelajaran dan 
memperkuat konsep merdeka belajar dalam pembelajaran daring (Kemdikbud, 2020). Untuk kedepannya pasca pandemi, dengan adanya kemajuan teknologi seperti internet memberikan manfaat yang dapat diterapkan baik untuk institusi, dosen maupun mahasiswa. Pola pembelajaran dapat dilakukan dengan mengkombinasikan (blended learning) antara tatap muka (luring) dan daring. Selain itu, bagi institusi dapat mengatasi keterbatasan ruangan kelas, bagi dosen dapat memanfaatkan waktu luang untuk meneliti dan melakukan pengabdian kepada masyarakat, sedangkan bagi mahasiswa terbantu untuk tidak perlu datang ke kampus untuk belajar, namun cukup melalui internet, terutama bagi para mahasiswa yang kuliah sambil bekerja (Isman, 2017). Bentuk pembelajaran model blended learning ini memungkinkan tercapainya pengembangan kompetensi mahasiswa belajar secara optimal, efektif dan efisien yang pada akhirnya meningkatkan kemandirian belajar mahasiswa (Firman \& Rahayu, 2020).

\section{Daftar Pustaka}

Firman, \& Rahayu, S. (2020). Pembelajaran Online di Tengah Pandemi Covid-19. Indonesian Journal of Educational Science (IJES), 2(2), 81-89. https://doi.org/10.31605/ijes.v2i2.659

Handayanto, R. T., \& Herlawati, H. (2020). Efektifitas Pembatasan Sosial Berskala Besar (PSBB) di Kota Bekasi Dalam Mengatasi COVID-19 dengan Model Susceptible-InfectedRecovered (SIR). Jurnal Kajian IImiah, 20(2), 119-124. https://doi.org/10.31599/jki.v20i2.119

Herlawati, H. (2020). COVID-19 Spread Pattern Using Support Vector Regression. PIKSEL: Penelitian IImu Komputer Sistem Embedded and Logic, 8(1), 67-74. https://doi.org/10.33558/piksel.v8i1.2024

Isman, M. (2017). Pembelajaran Moda dalam Jaringan (Moda Daring). The Progressive and Fun Education Seminar.

Kemdikbud, pengelola web. (2020). Kemendikbud Terbitkan Pedoman Penyelenggaraan Belajar dari Rumah. Jakarta, 28 Mei 2020.

Kemendikbud, H. D. P. T. (2020). Praktik Baik Pembelajaran Daring di Perguruan Tinggi Masa Pandemi Covid-19. Siaran Pers Nomor : 030/Sipers/IV/2020.

Pakpahan, R., \& Fitriani, Y. (2020). Analisa Pemanfaatan Teknologi Informasi dalam Pembelajaran Jarak Jauh di Tengah Pandemi Virus Corona Covid-19. Journal of Information System, Applied, Management, Accounting and Research, 4(2), 30-36.

Rohman, M. G., \& Munif, M. (2020). PENGEMBANGAN E-LEARNING MENGGUNAKAN MOODLE DI UNIVERSITAS ISLAM LAMONGAN. Joutica, 5(1), 350-355. https://doi.org/10.30736/jti.v5i1.414

SPADA Indonesia. (2019). Panduan Proses Pembelajaran Daring SPADA 2019. Panduan Kementrian RISTEKDIKTI.

Sugiyono. (2018). Metode Penelitian Kuantitatif,Kualitatif dan R\&D. In ke-26. 